\title{
Counterculture Of 1960-S and «Underground Press» in the Usa
}

\section{Contracultura de 1960-S y «Underground Press» en Estados Unidos}

\section{Oleg Vyacheslavovich Bodrov}

Candidate of Historical Sciences, Associate Professor, Department of Regional Studies and Eurasian Studies, Institute of International Relations, Kazan Federal University

ORCID ID: https://orcid.org/0000-0002-8394-7210

\author{
Almaz Vasilovich Zakirov \\ Candidate of Historical Sciences, Senior Lecturer, Department of Regional Studies and Eurasian \\ Studies, Institute of International Relations, Kazan Federal University \\ ORCID ID: https://orcid.org/0000-0003-4562-897X

\section{Luiza Kajumovna Karimova} \\ Candidate of Historical Sciences, Associate Professor, Department of Regional Studies and \\ Eurasian Studies, Institute of International Relations, Kazan Federal University \\ ORCID ID: https://orcid.org/0000-0002-0353-8493
}

\section{Anna Andreevna Kirpichnikova}

$\mathrm{PhD}$ in Philology, senior lecturer, Department of Foreign Languages, Institute of International Relations, Kazan Federal University

ORCID ID: https://orcid.org/0000-0003-4261-8004

Received 09-08-20 Revised 10-10-20

Accepted 20-12-21 On line 02-16-21

\section{* Correspondence}

Email: almazakiro@yandex.ru

\section{Citation:}

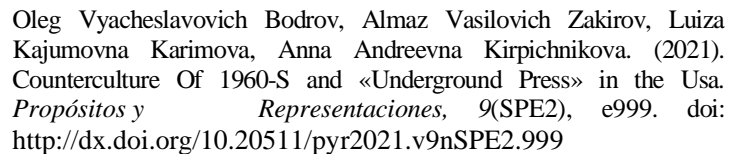

Oleg Vyacheslavovich Bodrov, Almaz Vasilovich Zakirov, Luiza Counterculture of $1960-\mathrm{S}$ and «Underground Press" in the Usa. Representaciones, 9(SPE2), e999. doi: http://dx.doi.org/10.20511/pyr2021.v9nSPE2.999 


\section{Summary}

The Underground Press Syndicate (UPS), later known as Alternative Press Syndicate (APS), was a chain of countercultural newspapers and magazines created in the middle of 1966 by publishers of five early underground newspapers «The East Village Other», «The Los Angeles Free Press», «The Berkeley Barb», «The Paper» and «Fifth Estate». By 1974 the majority of underground papers in the USA ceased to exist but they had an impact on journalistic processes during 1970-s that led to the press development in small towns and countryside giving alternative opinion about local news, cultural news, Native Americans' politics, ecology, youth and anti-military movements. The article considers the history of "underground press" in the USA, its role and importance for Countercultural Revolution of the 1960-s, which was countrywide in the USA and covered all areas of life.

Keywords: the USA, counterculture, The Underground Press Syndicate, underground press

\section{Resumen}

The Underground Press Syndicate (UPS), más tarde conocido como Alternative Press Syndicate (APS), era una cadena de periódicos y revistas contraculturales creada a mediados de 1966 por los editores de los cinco primeros periódicos clandestinos «The East Village Other», «The Los Angeles Free Press », « The Berkeley Barb », « The Paper »y« Fifth Estate ». En 1974, la mayoría de los periódicos clandestinos en los EE. UU. Dejaron de existir, pero tuvieron un impacto en los procesos periodísticos durante la década de 1970 que llevaron al desarrollo de la prensa en pueblos pequeños y en el campo, dando una opinión alternativa sobre noticias locales, noticias culturales, la política de los nativos americanos, ecología, juventud y movimientos antimilitares. El artículo considera la historia de la "prensa clandestina" en los Estados Unidos, su papel e importancia para la Revolución Contracultural de la década de 1960, que se extendió por todo el país en los Estados Unidos y cubrió todas las áreas de la vida.

Palabras clave: Estados Unidos, contracultura, The Underground Press Syndicate, prensa underground.

\section{Introduction}

Countercultural Revolution of the 1960-s, covered all areas of American society life "from war to sex", would not have become possible if there had not been new communication system. At that time, the USA had three main television networks and two wire services, which conveyed single package of international and national news to daily newspapers. "Underground press" rushed into this monopoly publishing articles on such topics and with such points of view that could not be found in official press and using graphics and design which made a contrast with them (McMillian, 2011).

"Underground press" of 1960-s was inspired by predecessors of 1950-s such as weekly "Village Voice» and satiric newspaper "The Realist" by Paul Krassner (Krassner, 2004). «Los Angeles Free Press» established in 1964 and firstly published in 1965 was probably the first underground newspaper (Glessing, 1970).

Countercultural media came into "Golden Era" after verdict of United States Supreme Court in 1966 on a claim "of Sheppard versus Maxwell" that expanded press freedom, expending the effect of the first amendment of United State Constitution (http://summerof.love). In California, there was the greatest amount of such newspapers -452 followed by New York and Illinois. However, they could be found in every state and not only in big cities but in university campuses (http://depts.washington.edu). 
Thus, in 1960-s two new types of underground newspapers appeared: the first focused on politics and the second specialized in spiritual sphere - art and culture. For example, among two best-known Californian newspapers in the Bay Area, political one was «Berkeley Barb», daily newspaper published from 1965 to 1980 and established by Max Scherr and countercultural one was «San Francisco Oracle», underground paper published in Haight-Ashbury from September, 1966 to February, 1968 and established by poet Allen Cohen and artist Michael Bowen. New periodic media of San Francisco were absolutely different from other underground papers. For instance, «Berkeley Barb» was the avant-garde of left-wing activists and protested against Vietnam War. "Children of flowers" supported «San Francisco Oracle» thought about love and non-violence more and considered Golden Gate Park as the best place for sit-down strike (http://summerof.love).

\section{Methods}

This research uses general scientific methods such as analysis, synthesis, comparison, classification, etc. Moreover, principle of historicism is used that allows considering historical processes and phenomenon while developing and in connection with different areas of social life and historical-genetic method is applied that gives an opportunity to show sequence of events and transformation process of American society in general and the impact of "underground press" on this process.

\section{Results}

Many big cities had underground newspapers. The majority of these newspapers were political or were established as political response to Vietnam War but some of them such as "East Village Other" in New York and "Chicago's Seed" in Chicago started to induce cultural and esthetic innovations such as "Oracle". Newspapers tried to unite local societies through the idea of protest using propaganda and informing about plans, debates and demonstrations of movement (Wachsberger, 2012). Every big city, the majority of universities and campuses and even secondary schools had alternative media during next five years. Writers, artists, satirists, caricaturists and poets got an opportunity to realize their ideas and tribune for communication with likeminded people. In spring, 1967, about 20 periodicals were being published and they focused on idea of political and cultural protest (Allen Cohen and the S.F. Oracle).

Publishers of "underground press" first relied on street sell getting 10 cents for one newspaper sold. Free distribution started in 1970-s and it began with newspapers of military communities and students' residence halls distributed for free. At the end, the majority of newspapers started being distributed for free relying on advertising revenue. By 1972-1973 "underground press" started being called "alternative press" (http://depts.washington.edu). Staff of such media usually did not get salary and resembled the army of trainees. Their articles did not provide objective facts and expressed authors' opinion (http://summerof.love).

Every city had at least one underground paper with large circulation: "Village Voice" in New York (130 000 readers), "Los Angeles Free Press" (100 000), "Rag" in Austin (10 000), "Phoenix" in Boston and "Paper" in East Lansing (Michigan). Bay Area in San Francisco became home for several underground papers: «Berkeley Barb» (85 000), «San Francisco Bay Guardian» (30 000) и «Black Panther» (85 000).

During Vietnam War, more than 300 soldier underground papers were being published. For example, Pacific Northwest Region had such papers as "Counterpoint", "Fed Up!", "LewisMcChord Free Press" and "GI Voice" from military base in Fort Lewis and McChord Air Force Base near Tacoma (Washington); news-bulletin of forces "B Troop News" and "First of the Worst" and "Yah-Hoh" from Fort Lewis; "Sacstrated" and "Co-Ambulation" from Fairchild Air Force Base (Washington); "Puget Sound Sound Off" from Bremerton Navy Yard (Washington) (Kindig, 2008). 
Although at the beginning among "underground press", there were male-oriented outlets, in time, the amount of feminists newspapers increased, which included Chicago's "Majority Report", Washington, D.C.'s "Off Our Backs", and Baltimore's "Women: A Journal of Liberation", each of which had about 20,000 readers (http://depts.washington.edu).

One of the most famous underground papers of 1960-s was the "San Francisco Oracle". Process of creation of this newspaper, novelty of its form and content, creative skill and managerial capabilities of the founders, inextricable connection with The Haight Ashbury countercultural movement and "Mind Blowing Revolution"... All these facts and many others make the newspaper the most representative while the study of "underground press" role and place in the time of sociocultural changes of 1960-s.

The initial impetus for the paper came from San Francisco poet Allen Cohen and owners of "Psychedelic" Shops Ron and Jay Thelin who became first sponsors. In the summer of 1966 several meetings were held in the Haight-Ashbury district and as the result the newspaper "P.O. Frisco" ("Psychedelphic Oracle") appeared and the its first issue was published on September $20^{\text {th }}$, 1966. After inner reorganization and editorial board renewal, the newspaper was renamed into "The San Francisco Oracle" that fully reflected its oracular idealism. Allen Cohen became a new editor and Californian artist Michael Bowen became an artistic director.

The newspaper staff consisted of great amount of artists, writers, technical workers and businessmen, including poet Stephen Levine, Texan Travis Rivers, who brought Janis Joplin and Tracy Nelson to San Francisco; Greek poet and writer George Tsongas; designers Hetti McGee from Liverpool, Ami McGill and Gabe Katz; poet and traveler Harry Monroe; the best graphic designer of South Caroline Ashton Dangerfield, former marine Gene Grimm, and Steve Lieper from Tennessee. Among artists, who illustrated "The Oracle" (often anonymously), there were Mark Devries, Steve Schafer, Michael Ferar, Armando Busick, and Gary Goldhill, etc. Owing to their collection, creative work and dedication "The Oracle" became unique monument of American art and literature (Allen Cohen and the S.F. Oracle).

The Oracle was a collective product, owned by workers themselves. It appeared owing to sponsors' donations and then existed through retail sales. The newspaper got donations from Alex Geluardi, who was marijuana dealers and a benefactor and comforter to many San Francisco writers and artists; owner of "Psychedelic" Shop Jay Thelin gave money which were unsecured $\$ 6,000$ loan from the bank; Bill Graham, the rock impresario, lent $\$ 1000$; however, the only outright donation $\$ 5,000$ was got from Peter Tork of the TV rock group, the Monkees (Allen Cohen and the S.F. Oracle).

Allen Cohen pointed out that "The Oracle" did not have ideological platform. "Though the Oracle staff didn't have a political program, we did feel that we were involved in a worldwide process of transformation that was part revolution and part renaissance. There was a mystique of youth that was based on the conception that the powers that ruled the world were decadent, corrupt and calcified. Therefore, the future was perceived as youths' responsibility to create and remold. There was also a moral revulsion against modern technological civilization for its failure to regenerate the world according to the principles of economic justice and peace. Most of us wanted the conversion of the dying past to come about through a spiritual transformation that fostered the values of love, peace and compassion, and brought us back to simple earth-based tribal groups. "The Oracle" would be a vehicle for new and ancient models that were needed to guide these changes in consciousness and to reconstruct our world" (Allen Cohen and the S.F. Oracle).

In order to coordinate their actions five independent media created The Underground Press Syndicate (UPS) in 1966 in different cities of the USA, lately known as Alternative Press Syndicate (APS). The first media was "Los Angeles Free Press" which had been published since May 1964 and was known as "The Faire Free Press". Shortly after, "Berkeley Barb" appeared in August 1965, "East Village Other" - in October 1965 in New York, "Fifth Estate" - in November 1965 in Detroit and "East Lansing's The Paper" - in December 1965. While developing The 
Underground Press Syndicate created the chain of publishing houses with underground press center and then with its own magazine.

The publisher Allen Cohen writes about the meeting in San Francisco "The Oracle staff, motivated by Ron Thelin's vision of a nationwide "tribal messenger service", decided to host an underground press conference. We invited all the papers that were already loosely allied as the Underground Press Syndicate. We also wanted to show the editors how to adapt the innovations we were making in the Oracle, and expose them to the burgeoning Haight-Ashbury community that was then at its peak of creativity, and spontaneous interactive compassion... The first UPS conference was held at Michael Bowen's house on Stinson Beach, and the Oracle's offices during Easter, 1967. Some of the participants included Art Kunkin of the L.A. Free Press, Allan Katzman and Walter Bowart of the East Village Other (EVO), Max Scheer of the Berkeley Barb, and representatives of Detroit's Fifth Estate, Chicago's Seed, Mendocino's Illustrated Paper, Austin's Rag and a few other papers..... Some of the Diggers including Peter and Judy Berg and Chester Anderson barged uninvited into the conference with the intention of exposing our elitism" (Allen Cohen and the S.F. Oracle).

The Syndicate's Charter was adopted at the official conference, which was organized by UPS in June 1967 in the editors office of "Middle Earth" (Iowa). The purpose of the Syndicate was to warn the world about impending collapse. Members could freely reprint each other's content, which gave small papers access to a large amount of content and helped larger newspapers share their writing throughout the country and world. It allowed local media to spill over to immense territory and membership grew from 15 newspapers in November 1966 to 271 papers in 1971 reaching Canada and Europe (http://depts.washington.edu).

According to Allen Cohen, during the meeting in "San Francisco Oracle" in March 1967 there was an attempt to form general principles concerning the work of underground press all over America. In order to achieve this purpose it was allowed to publish commercial advertisements from independent sources not counting monopolists in media sphere and highlighting psychedelic, socio-cultural and political materials. It was said, "We were creating, maintaining and informing a new international community which would ultimately replace the crumbling status quo" (Allen Cohen and the S.F. Oracle).

There were also following main points: To warn the "civilized world" of its impending collapse, through communications among aware communities outside the establishment and by attracting the attention of the mass media, to note and chronicle events leading to the collapse, to prepare the American public for the wilderness, to fight a holding action in the dying cities. All these statements indicate apocalyptic feeling of the time and war seemed to be the symptom of the general fall of the American civilization (Allen Cohen and the S.F. Oracle).

Another news source was Liberation News Service (LNS) founded in 1967 and belonged to New Leftists, which could be characterized as anti-war underground press news service joining another part of "underground press" which distributed independent information from 1967 to 1981.

Marshall Bloom and Raymond Mungo, former editors of the student newspapers, founded LNS after they had left the United States Student Press Association. The Service attracted the attention of the "underground press" to protests in Pentagon in October 1967 and in Columbia University in 1968 (https://www.nybooks.com). By 1972 the Service had about 800 subscribers and sent content twice a week. It was voluntary and relied on financing through subscribers and donations (http://depts.washington.edu).

By February 1968, among LNS subscribers, there were 150 underground newspapers and 90 student newspapers; average subscription cost 100 dollars a year. The Service was supported by famous journalists and activists such as I. F. Stone, Jack Newfield, Nat Hentoff and William Kunstler. Its readership was estimated to be two millions (http://scua.library.umass.edu). 
As underground papers appeared, they caught the attention of the United States Government. There were mass revolts in black neighborhoods in summer 1967, in a move that foreshadowed the Nixon Administration's Interagency Committee on Intelligence, the Central Intelligence Agency (CIA) and the National Security Agency (NSA) combined forces to enlarge a program aimed at finding "foreign influences" on domestic unrest in 1967. The Armed Forces intelligence program was also expanded to include civil disorder and military began spying on civilians. Even the Internal Revenue Service (IRS) was used as a surveillance tool. This type of government intervention and the consistent strain of legal fees proved to be a death knell for many publications, even while this attention simultaneously justified their work. The 1960s may have been a golden era for underground journalism, but the radical enlargement of domestic surveillance in the 1970s soon saw to its demise (http://summerof.love).

Thus, "the underground press" boom started to go down by 1970-s and it finished by 1973. After the meeting of UPS representatives in Boulder, Colorado in 1973, the organization got a new name - Alternative Press Syndicate, which was used until 1974. By 1974, the majority of underground newspapers disappeared. Despite this fact, local underground press became a legend, that why it had impact on people during 1970-s and even latter suggesting alternative point of view on political news and culture as well as on native Americans' problems, ecology, peaceful coexistence, etc (http://depts.washington.edu).

\section{Discussion}

In western historiography, the problems of "underground press" development and its impact on changes in opinions and values in American society in 1960-s - early 1970-s, history of separated media and individuals linked to this process was considered in books by McMillian J. (McMillian, 2011), Glessing R.J. (Glessing, 1970), Wachsberger K. (Wachsberger, 2012), articles by Meldahl N. (http://summerof.love), Anastas K. (http://depts.washington.edu), etc.

Modern Russian historiography does not consider this topic, however, there are some works devoted to different informal movements, music's impact on social and cultural sphere in the USA, problems of traditional and non-traditional values in USA political discourse in 1960-s (Krassner, 2004).

Thus, there are no scientific works with a complex approach to the history of USA "underground press" and its impact on American counterculture formation in 60-70-s. and this fact makes the problem relevant for modern researchers in the sphere of America studies

\section{Summary}

"Underground press" born during countercultural revolution of 1960-s allowed protest groups of fighters for civil rights, feminists, anti-military movement, student activists to provide information independent from official media, information which was more emotional and personal than other existing informational sources.

"Underground press" spilled over to entire territory of the USA from east to west, existed in metropolitan cities as well as in student campuses and military bases. Newspapers could be divided into several groups such as political and cultural, male and female, aimed at white-skin, African Americans and Chicanos. "The Underground press" promoted the increase in the interests to political and social life in the country, made people more involved in the process of changes and critical thinking of Vietnam War in general.

\section{Conclusions}

Nowadays social nets have the same capability as "underground press" to mobilize civil activism and establish new movements. Moreover, contemporary activists can create web-sites, web blogs and profile in different social nets everybody can release a newspaper over the Internet, a 
newspaper with unique content and style. Online as well as offline, contemporary authors support the methods "Do it yourself", which made "underground press" successful.

\section{Acknowledgements}

The work is performed according to the Russian Government Program of Competitive Growth of Kazan Federal University.

\section{References}

"Liberation News Service Records." Special Collections and University Archives. UMass Amherst Libraries URL: http://scua.library.umass.edu/umarmot/liberation-news-service/

Allen Cohen and the S.F. Oracle. URL: http://www.rockument.com/blog/haight-ashbury-in-thesixties/allen-cohen-and-the-s-f-oracle/

Anastas, K. Underground newspapers: The social media networks of the 1960s and 1970s. URL: http://depts.washington.edu/moves/altnews_geography.shtml

Glessing, R.J. (1970). The Underground Press in America. Bloomington: Indiana UP.

Kindig, J. (2008). GI Papers at Fort Lewis.” Antiwar and Radical History Project - Northwest. Pacific Northwest Labor and Civil Rights Projects. URL: http://depts.washington.edu/labpics/zenPhoto/antiwar/gipaper/

Krassner, P. (2004). Slaughtering Cows and Popping Cherries. New York Press, 16(34). URL: https://web.archive.org/web/20040208104724/http://www.nypress.com/16/34/news\%26col umns/feature.cfm

McMillian, J. (2011). Smoking Typewriters: The Sixties Underground Press and the Rise of Alternative Media in America. Oxford University Press.

Meldahl, N. News is a State of Mind: Allen Cohen and The San Francisco Oracle. URL: http://summerof.love/news-state-mind-allen-cohen-san-francisco-oracle/

Ogorodova, A.V., Ovcharov, I.V., \& Orshanskaya, E.I. (2019). Interrelation of Jazz and SocioCultural Situation in the USA in the 1960s // http://www.rockument.com/blog/haightashbury-in-the-sixties/allen-cohen-and-the-s-f-oracle/Manuscript, 12(9), 176-181.

Stone, I.F., Newfield, J, Hentoff, N., \& Knustler, W. (1972). "LNS." Liberation News Service. NY. URL: https://www.nybooks.com/articles/1972/09/21/lns/

Underground Press Database. URL: http://depts.washington.edu/moves/altnews_database.shtml

Wachsberger, K. (2012). Insider Histories of the Vietnam Era Underground Press, Part 2. East Lansing: Michigan State University. 